Investigation of the Kinetics and Products Resulting from the Reaction of Peroxone with Aminodinitrotoluenes

Ronald J. Spanggord, David Yao, and Theodore Mill 
Abstract: The reaction between peroxone and two isomers of aminodinitrotoluene (ADNT) was studied with respect to kinetics of reaction and the products formed. The ADNTs react rapidly with ozone and hydroxyl radical, the principal components of peroxone. At fairly high ADNT concentrations (ppm), the re- action of ADNT is primarily with ozone. At lower ADNT concentrations $(\mathrm{ppb})$, hydroxyl radical competes with ozone in pure water systems. Reactions of both the 2and 4-ADNT isomers result in the formation of pyruvic acid, nitrate ion, and nitrite ion. A reaction mechanism consistent with these products is proposed.

How to get copies of CRREL technical publications:

Department of Defense personnel and contractors may order reports through the Defense Technical Information Center:

DTIC-BR SUITE 0944

8725 JOHN J KINGMAN RD

FT BELVOIR VA 22060-6218

Telephone 18002253842

E-mail help@dtic.mil

msorders@dtic.mil

WWW http://www.dtic.dla.mil/

All others may order reports through the National Technical Information Service:

NTIS

5285 PORT ROYAL RD

SPRINGFIELD VA 22161

Telephone 17034874650

17034874639 (TDD for the hearing-impaired)

E-mail_orders@ntis.fedworld.gov

WWW http://www.fedworld.gov/ntis/ntishome.html

A complete list of all CRREL technical publications is available from:

USACRREL (CECRL-TL)

72 LYME RD

HANOVER NH 03755-1290

Telephone 16036464338

E-mail_techpubs@crrel.usace.army.mil

For information on all aspects of the Cold Regions Research and Engineering Laboratory, visit our World Wide Web site: http://www.crrel.usace.army.mil 


\section{Special Report 97-5}

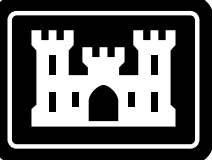

US Army Corps

of Engineers $\otimes$

Cold Regions Research \&

Engineering Laboratory

\section{Investigation of the Kinetics and Products Resulting from the Reaction of Peroxone with Aminodinitrotoluenes}

Ronald J. Spanggord, David Yao, and Theodore Mill 


\section{PREFACE}

This report was prepared by Dr. Ronald J. Spanggord, Director, Bio-Analytical Chemistry Program, Life Sciences Division, and by Dr. David Yao, Research Chemist, and Dr. Theodore Mill, Senior Scientist, Chemistry Laboratory, Physical Sciences Division, SRI International, Menlo Park, California. Funding was provided by the U.S. Army Cold Regions Research and Engineering Laboratory (CRREL) and the U.S. Army Engineer Waterways Experiment Station (WES), Thomas F. Jenkins (CRREL) and Elizabeth Fleming (WES), Project Monitors, under the Strategic Environmental Research and Development Program (SERDP).

The authors gratefully acknowledge Daniel Leggett and Thomas F. Jenkins, CRREL, for their technical review of this manuscript, and Dr. Mark Zappi of Mississippi State University (formerly of WES) for initiating financial support for this research.

This publication reflects the personal views of the authors and does not suggest or reflect the policy, practices, programs, or doctrine of the U.S. Army or Government of the United States. The contents of this report are not to be used for advertising or promotional purposes. Citation of brand names does not constitute an official endorsement or approval of the use of such commercial products. 


\section{CONTENTS}

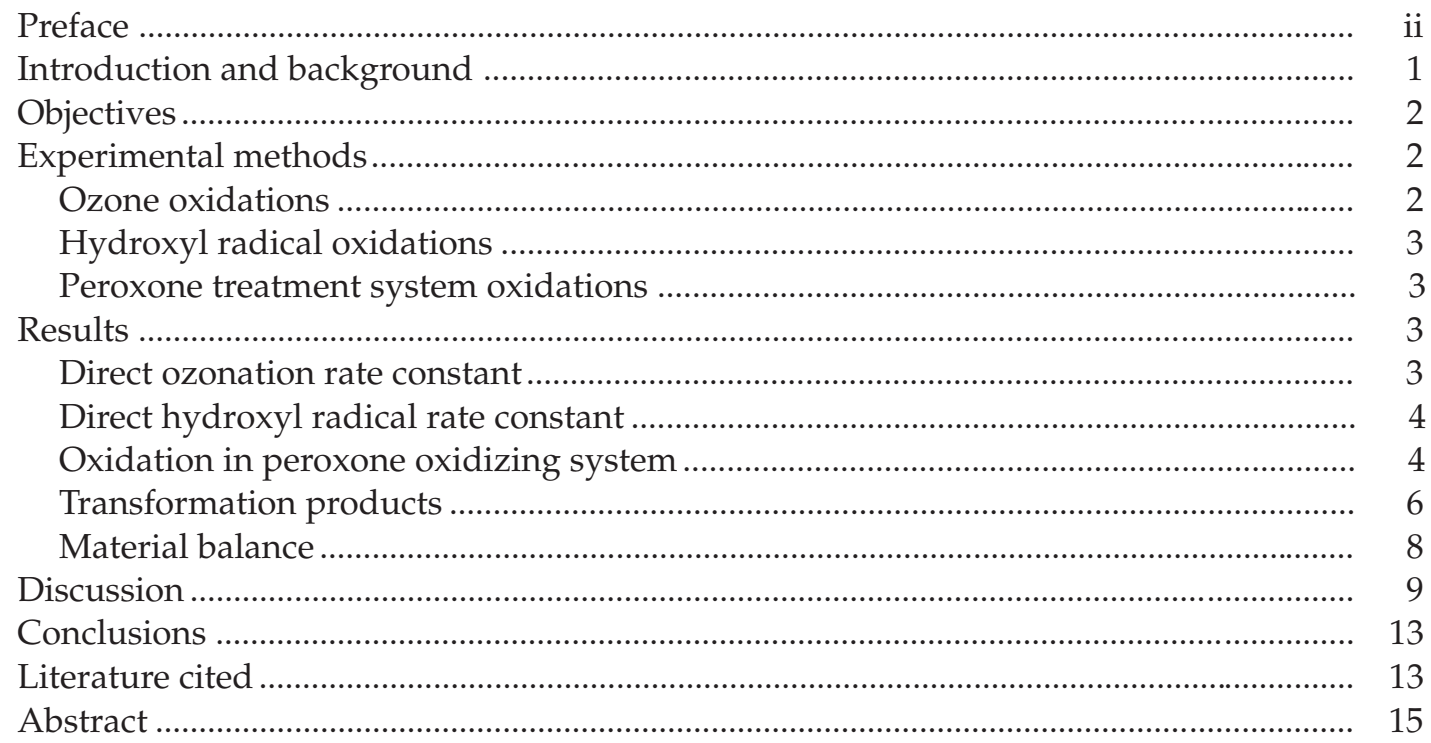

\section{ILLUSTRATIONS}

Figure

1. Measured ozone rate constants for 2-ADNT and 4-ADNT against the reference chemical, nitrite

2. Measured hydroxyl radical rate constants for 2-ADNT and 4-ADNT against the reference chemical, p-nitroacetophenone

3. Oxidation stoichiometry of 4-ADNT and 2-ADNT in the peroxone, ozone alone, and ozone with scavenger systems

4. HPLC profile of carbonyl-containing products from the ozonation of 2-ADNT .......

5. HPLC profile of carbonyl-containing products from the ozonation of 4-ADNT .......

6. UV spectral data for 4-ADNT compared to glyoxal and pyruvic aldehyde

7. Quantitative determination of 2,4-dinitrophenylhydrazone derivatives of products from 2-ADNT and 4-ADNT

8. HPLC profile of carboxylic acids formed from the ozonation of 4-ADNT and 2-ADNT using UV detection at $210 \mathrm{~nm}$ . 9 3 3 5 


\title{
Investigation of the Kinetics and Products Resulting from the Reaction of Peroxone with Aminodinitrotoluenes
}

\author{
RONALD J. SPANGGORD, DAVID YAO, AND THEODORE MILL
}

\section{INTRODUCTION AND BACKGROUND}

The U.S. Army is interested in using Advanced Oxidation Technologies (AOTs) for the treatment of wastes, residues, and contaminated groundwater resulting from past and present military manufacturing and chemical handling practices. One AOT of interest is the use of peroxone. Peroxone is a mixture of ozone $\left(\mathrm{O}_{3}\right)$ and hydrogen peroxide $\left(\mathrm{H}_{2} \mathrm{O}_{2}\right)$ that, when mixed together at a 1:1 ratio at $\mathrm{pH}>7$, generates hydroxyl radical $(\mathrm{HO} \bullet)$, which is a powerful oxidant. Ozone is also a strong oxidant of organic molecules in aqueous solution and offers competitive oxidative pathways in a peroxone system. Hydrogen peroxide may contribute to some oxidation of organics, but because of the reactivity of ozone with hydrogen peroxide, ozone and hydroxyl radical will dominate the oxidative process.

TNT (2,4,6-trinitrotoluene) is a major land contaminant at military installations, including TNT manufacturing sites and load and pack (LAP) facilities. Once introduced into the soil, TNT can undergo both aerobic and anaerobic microbial transformations that lead to 4-amino-2,6-dinitrotoluene (4-ADNT) and 2-amino-4,6-dinitrotoluene (2-ADNT). The structures of these chemicals are shown below.

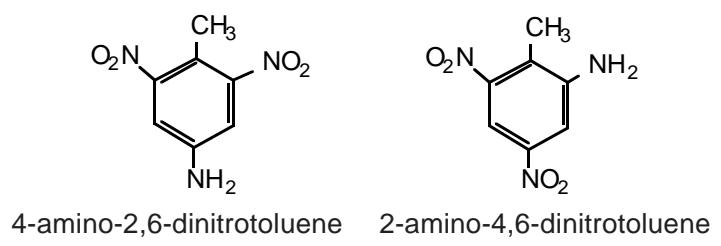

These compounds are currently being found in groundwater at munitions facilities. The use of an AOT technology will involve the oxidation of TNT transformation products. It therefore becomes important to understand oxidation rates, pathway, and stable end-products to make an assessment of the safety of peroxone treatment of ADNT-contaminated waters.

Oxidation rates can be described by simple second-order rate expressions. The kinetic rate expressions for oxidation by ozone and hydroxyl radical processes are shown in eq 1 and 2 . The overall loss can be described by eq 3 .

$$
\begin{aligned}
& \mathrm{ADNT}+\mathrm{O}_{3} \longrightarrow \mathrm{k}_{1} \text { Products } \quad d[\mathrm{ADNT}] / d t=\mathrm{k}_{1}[\mathrm{ADNT}]\left[\mathrm{O}_{3}\right] \\
& \mathrm{ADNT}+\mathrm{HO} \longrightarrow \mathrm{k}_{2} \text { Products } \quad d[\mathrm{ADNT}] / d t=\mathrm{k}_{2}[\mathrm{ADNT}][\mathrm{HO} \bullet] \\
& d[\mathrm{ADNT}] / d t=\mathrm{k}_{1}[\mathrm{ADNT}]\left[\mathrm{O}_{3}\right]+\mathrm{k}_{2}[\mathrm{ADNT}][\mathrm{HO} \bullet]=\left(\mathrm{k}_{1}\left[\mathrm{O}_{3}\right]+\mathrm{k}_{2}[\mathrm{HO} \bullet]\right)[\mathrm{ADNT}]
\end{aligned}
$$

Equation 3 shows that $\left[\mathrm{O}_{3}\right]$ and $[\mathrm{HO} \bullet]$ and the rate constants $\left(\mathrm{k}_{1}\right.$ and $\left.\mathrm{k}_{2}\right)$ will control the rate of ADNT disappearance. 
The rate constants for oxidizing ADNTs are not known, but their range can be estimated from known compounds and structure activity relationships (SARs). For example, the rate constant for the reaction of aniline with ozone is $9 \times 10^{7} \mathrm{M}^{-1} \mathrm{~s}^{-1}$ (Buxton and Greenstoch 1988). ADNT has two electron-withdrawing nitro groups and one electron-donating methyl group, so a rate constant for ozone oxidation of ADNT should be in the $10^{4}$ to $10^{7} \mathrm{M}^{-1} \mathrm{~s}^{-1}$ range. Estimation of the hydroxyl radical oxidation rate constant is possible because the related compound, p-nitroaniline, is known to have a hydroxyl radical rate constant of $10^{10} \mathrm{M}^{-1} \mathrm{~s}^{-1}$ (Buxton and Greenstoch 1988). Therefore, the rate constant for ADNT oxidation by hydroxyl radical is expected to be in the $10^{9} \mathrm{M}^{-1} \mathrm{~s}^{-1}$ range. In peroxone oxidizing systems, oxidant concentrations range from $10^{-4} \mathrm{M}$ for ozone to $10^{-14} \mathrm{M}$ for hydroxyl radical. We have used these values as a guide for our rate determination experiments.

When rate constants exceed $10^{4} \mathrm{M}^{-1} \mathrm{~s}^{-1}$, half-lives become extremely short $(\approx 1 \mathrm{~s})$ and it is difficult to measure oxidant and substrate loss. This problem can be solved by competitive oxidation of the substrate $(S)$ in the presence of a reference compound $(R)$ with a known rate constant for oxidation by a specific oxidant. In this case, the rate constant for the oxidation of the substrate is

$$
\mathrm{k}_{\mathrm{S}}=\mathrm{k}_{\mathrm{R}} \times \ln \left[\left(S_{\mathrm{o}}\right) /\left(S_{\mathrm{t}}\right)\right] / \ln \left[\left(R_{\mathrm{o}}\right) /\left(R_{\mathrm{t}}\right)\right]
$$

where $k_{S}$ and $k_{R}$ are the rate constants for the substrate and reference chemicals, respectively. For this study, we have used this approach to measure rate constants for the oxidation of 2-ADNT and 4-ADNT.

\section{OBJECTIVES}

The objectives of this study were to examine the kinetics of oxidative transformation of 4ADNT and 2-ADNT by the peroxone advanced oxidation process, identify stable end-products, and attempt to understand the oxidative pathway. We are interested in establishing rates of transformation and stable end-products resulting from the process and the mechanism by which these transformations occur.

\section{EXPERIMENTAL METHODS}

\section{Ozone oxidations}

Ozone oxidations were conducted in aqueous solutions adjusted to $\mathrm{pH} 5.0$ with phosphate buffer. Because the acid dissociation constants $\left(\mathrm{pK}_{\mathrm{a}} \mathrm{s}\right)$ of 2-ADNT and 4-ADNT are 1.23 and 0.59 (Glover et al. 1977), respectively, the amines are in their free form at this $\mathrm{pH}$. To inhibit concurrent hydroxyl radical transformations, some studies were conducted in the presence of $t$-butyl alcohol as a hydroxyl radical scavenger (Hoigne and Bader 1983). Ozone was generated from a Welsbach ozone generator and bubbled into water. Ozone concentration was determined by a standard colorimetric technique with indigo (Bader and Hoigne 1981).

An ozone stock solution was added in $20-\mu \mathrm{M}$ increments to a rapidly stirred stock solution of ADNT $(150 \mu \mathrm{M})$ and a reference chemical (nitrite or resorcinol). After each addition, the ADNT and resorcinol were analyzed by high-performance liquid chromatography (HPLC), and nitrite and nitrate by ion chromatography (Thayer and Huffaker 1980). Aldehydes and ketones were analyzed as their 2,4-dinitrophenylhydrazones according to the methods of Kieber and Mopper (1990). Carboxylic acids were analyzed by ion chromatography with a conductivity detector and by ion chromatography with UV detection as described below.

Ion chromatography with UV detection

Instrument: HP1081B liquid chromatograph

Column: Supelcogel C-610H (sulfonated polystyrene divinylbenzene), $7.8 \times 300 \mathrm{~mm}$ 
Solvent: $1 \% \mathrm{H}_{3} \mathrm{PO}_{4}$ in water

Flow rate: $0.5 \mathrm{~mL} / \mathrm{min}$

Detector: UV @ 210 nm

\author{
Ion chromatography with conductivity detection \\ Instrument: Dionex ion chromatograph \\ Column: PAX-500 \\ Solvent: $\mathrm{A}=200 \mathrm{mM} \mathrm{NaOH} ; \mathrm{B}=0.6 \mathrm{mM} \mathrm{NaOH} ; \mathrm{C}=5 \%$ methanol \\ Gradient: $T=0$ to $10 \mathrm{~min}$ : 0/25/75 (A/B/C) \\ $T=10$ to $15 \min : 10 / 65 / 25$ \\ $T=15$ to $30 \mathrm{~min}: 30 / 45 / 25$ \\ $T=30$ to 40 min: $30 / 45 / 25$ \\ $\mathrm{T}=40$ to $45 \mathrm{~min}: 0 / 75 / 25$ \\ Flow rate: $1.0 \mathrm{~mL} / \mathrm{min}$ \\ Anion suppressor: $27 \mathrm{mM} \mathrm{H}_{2} \mathrm{SO}_{4}$ \\ Detector: Conductivity
}

\title{
Hydroxyl radical oxidations
}

Hydroxyl radicals were generated using Fenton's system, where $\mathrm{Fe}^{+2}$ is oxidized to $\mathrm{Fe}^{+3}$ in the presence of hydrogen peroxide to generate hydroxyl radical as shown below.

$$
\mathrm{Fe}^{+2}+\mathrm{H}_{2} \mathrm{O}_{2} \longrightarrow \mathrm{Fe}^{+3}+\mathrm{HO} \bullet+{ }^{-} \mathrm{OH}
$$

In this system, hydrogen peroxide is incrementally added in the dark to freshly prepared $0.88 \mathrm{M}$ $\mathrm{Fe}\left(\mathrm{ClO}_{4}\right)_{2}$ solution containing the ADNT and p-nitroacetophenone (PNAP, internal reference chemical). The solution was stirred for $20 \mathrm{~min}$ and the ADNT and PNAP were analyzed directly by HPLC.

\section{Peroxone treatment system oxidations}

The efficiency of peroxone oxidations compared to oxidations by other potential oxidants in the peroxone system was determined in three experiments: one with ozone and $1.9 \mathrm{mM} t$-butyl alcohol as a $\mathrm{HO} \bullet$ scavenger; one using ozone alone; and one using ozone with $117 \mu \mathrm{M}$ hydrogen peroxide. In each of these experiments, ozone was added at $0,39,82$, or $182 \mu \mathrm{M}$ to stirred solutions of the ADNT. After each ozone addition, samples were removed for analysis of the ADNT by HPLC and remaining hydrogen peroxide by the titanium sulfate method (Setterfield and Bonnel 1955).

\section{RESULTS}

\section{Direct ozonation rate constant $\left(\mathrm{k}_{\mathrm{O}_{3}}\right)$}

Two reference chemicals, resorcinol and nitrite ion, with reported rate constants of $9.4 \times 10^{4}$ $\mathrm{M}^{-1} \mathrm{~s}^{-1}$ and $3.5 \times 10^{5} \mathrm{M}^{-1} \mathrm{~s}^{-1}$, respectively (Buxton and Greenstoch 1988), were selected for competitive kinetic studies with 2-ADNT and 4-ADNT. Both ADNTs disappeared in the presence of ozone; the data appear in Table 1.

First-order plots of 2-ADNT and 4-ADNT loss and reference compound loss (nitrite) appear in Figure 1. From eq 4 the rate constant for 2-ADNT loss was calculated to be $1.4 \times 10^{5} \mathrm{M}^{-1} \mathrm{~s}^{-1}$ with resorcinol as a reference and $5.3 \times 10^{5} \mathrm{M}^{-1} \mathrm{~s}^{-1}$ with nitrite as a reference. For 4-ADNT, the rate constants were $1.5 \times 10^{5} \mathrm{M}^{-1} \mathrm{~s}^{-1}$ and $1.9 \times 10^{5} \mathrm{M}^{-1} \mathrm{~s}^{-1}$.

Because the reaction of ozone with the ADNTs could generate hydroxyl radical, identical experiments were performed in the presence of twentyfold excess $t$-butyl alcohol as a hydroxyl radical scavenger. The loss of ADNTs was not affected (see "Oxidation in peroxone oxidizing system," 
below), which indicates that hydroxyl radical plays an insignificant role in the oxidation of ADNTs by ozone.

\section{Direct hydroxyl radical rate constant $\left(\mathrm{k}_{\mathrm{HO}}\right)$}

Most organics are oxidized by hydroxyl radical with rate constants in the range of $10^{9}$ to $10^{10} \mathrm{M}^{-1} \mathrm{~s}^{-1}$ (Buxton and Greenstoch 1988). We selected PNAP as a reference compound with an average hydroxyl radical rate constant of $3.1 \times 10^{9} \mathrm{M}^{-1} \mathrm{~s}^{-1}$ (Buxton and Greenstoch 1988). Average data (two determinations) for the loss of 2-ADNT and 4-ADNT with respect to PNAP are shown in Table 2.
Table 1. Loss of 2-ADNT and 4-ADNT $(\mu \mathrm{M})$ with ozone in the presence of resorcinol and nitrite reference chemicals.

\begin{tabular}{cccccc}
\multicolumn{7}{c}{$\begin{array}{c}\text { Rate } \\
\text { Resorcinol } \\
(\mu M)\end{array}$} & $\begin{array}{c}\text { constant } \\
\left(M^{-1} s^{-1}\right)\end{array}$ & $\begin{array}{c}\text { 2-ADNT } \\
(\mu M)\end{array}$ & $\begin{array}{c}\text { Nitrite } \\
(\mu M)\end{array}$ & $\begin{array}{c}\text { Ranstant } \\
\left(M^{-1} s^{-1}\right)\end{array}$ \\
\hline 2-ADNT & & & & & \\
10.5 & 15.5 & & 200 & 200 & \\
8.0 & 11.8 & & 148 & 164 & \\
5.8 & 8.2 & & 120 & 142 & \\
4.0 & 5.0 & & 93.4 & 122 & $5.3 \times 10^{5}$ \\
2.7 & 3.0 & $1.4 \times 10^{5}$ & & & \\
4-ADNT & & & & & \\
11.0 & 14.5 & & 300 & 300 & \\
9.4 & 11.8 & & 267 & 265 & \\
8.3 & 9.9 & & 233 & 183 & \\
6.1 & 6.0 & $1.5 \times 10^{5}$ & 192 & 139 & $1.9 \times 10^{5}$ \\
\hline
\end{tabular}

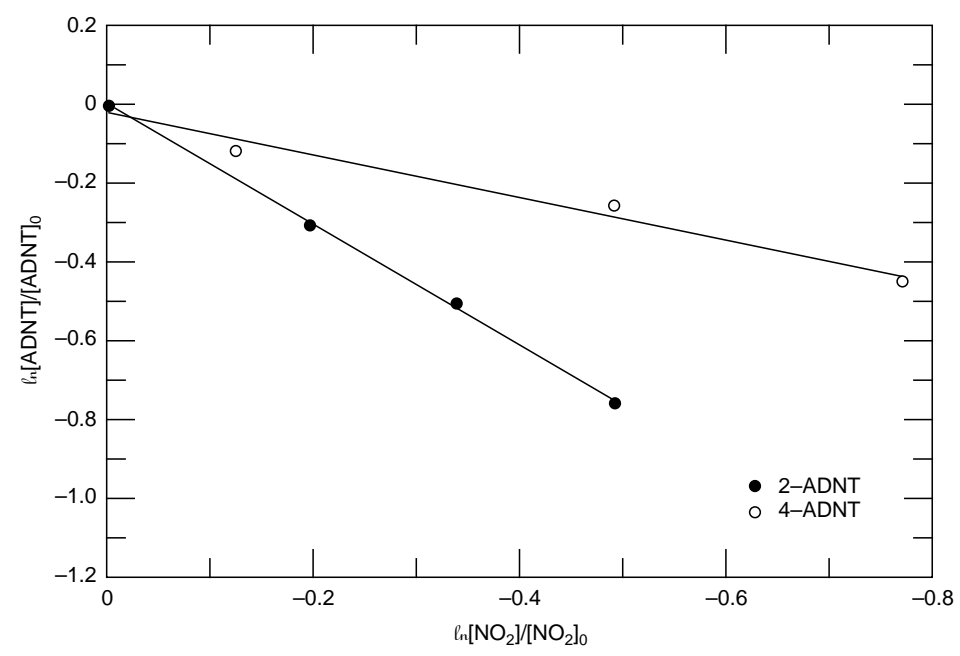

Figure 1. Measured ozone rate constants for 2-ADNT and 4ADNT against the reference chemical, nitrite.

Plots of the loss of ADNTs and PNAP appear in Figure 2. From eq 4, hydroxyl radical rate constants were calculated to be $1.6 \times$ $10^{9} \mathrm{M}^{-1} \mathrm{~s}^{-1}$ and $1.9 \times 10^{9} \mathrm{M}^{-1} \mathrm{~s}^{-1}$ for 2-ADNT and 4-ADNT, respectively.

\section{Oxidation in peroxone oxidizing system}

The reactions of the ADNTs with peroxone $\left(\mathrm{O}_{3} / \mathrm{H}_{2} \mathrm{O}_{2}\right)$, ozone, and ozone with $t$-butyl alcohol are depicted graphically in Figure 3. These linear plots of ADNT consumed versus ozone utilized indicate that hydroxyl radical, hydrogen peroxide, or the hydroxyl radical scavenger ( $t$-butyl alcohol) have little effect in the peroxone oxidation. These data suggest that the direct oxidation by ozone controls the oxidative process. In studying the stoichiometry of the transformation in the above three systems, we found that each mole of 2-ADNT consumes 2.5 moles of ozone. For 4-ADNT, the ratio was found to be similar: 2.7 moles ozone for each mole of 4-ADNT. If we consider that one mole of ADNT will react with one mole of ozone, then $\approx 60 \%[(2.5-1.0) / 2.5 \times$ $100]$ of the ozone is used to oxidize secondary products generated in the transformation, and these products are more reactive than the ADNT.
Table 2. Loss of ADNTs in the presence of hydroxyl radical.

\begin{tabular}{cccccc}
$\begin{array}{c}\text { 2-ADNT } \\
(\mu M)\end{array}$ & $\begin{array}{c}\text { PNAP } \\
(\mu M)\end{array}$ & $\begin{array}{c}\text { Ranstant } \\
\left(M^{-1} s^{-1}\right)\end{array}$ & $\begin{array}{c}\text { R-ADNT } \\
(\mu M)\end{array}$ & $\begin{array}{c}\text { PNAP } \\
(\mu M)\end{array}$ & $\begin{array}{c}\text { constant } \\
\left(M^{-1} s^{-1}\right)\end{array}$ \\
\hline 20.0 & 37.2 & & 20.0 & 37.2 & \\
18.7 & 31.5 & & 18.8 & 33.1 & \\
16.7 & 24.9 & & 17.3 & 28.9 & \\
14.9 & 20.0 & & 15.6 & 22.2 & \\
13.7 & 17.4 & & 13.6 & 19.3 & \\
12.6 & 14.7 & $1.9 \times 10^{9}$ & 12.4 & 16.6 & $1.6 \times 10^{9}$ \\
\hline
\end{tabular}




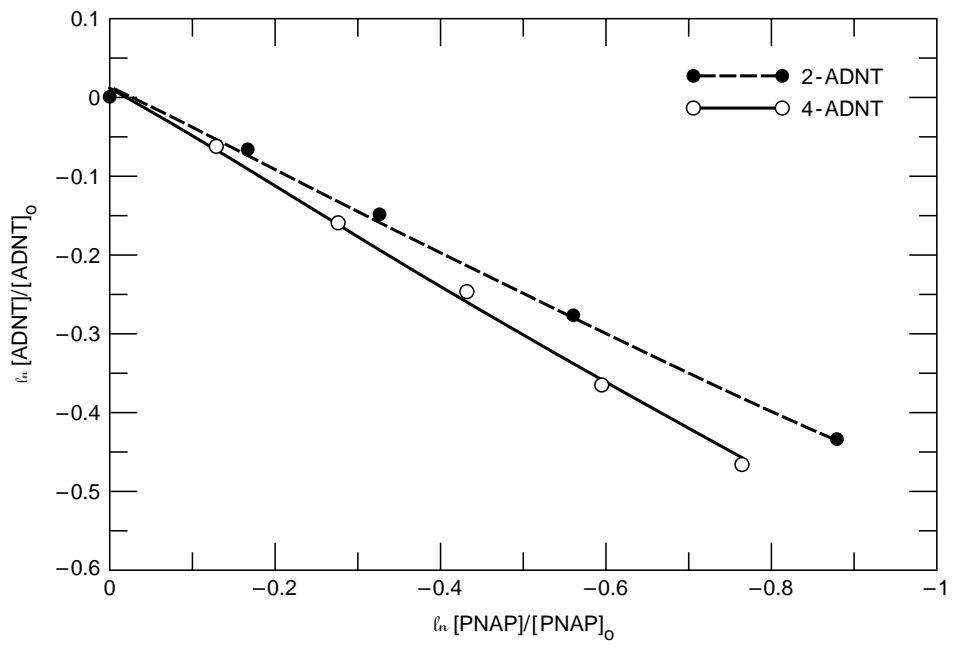

Figure 2. Measured hydroxyl radical rate constants for 2-ADNT and 4-ADNT against the reference chemical, p-nitroacetophenone (PNAP).

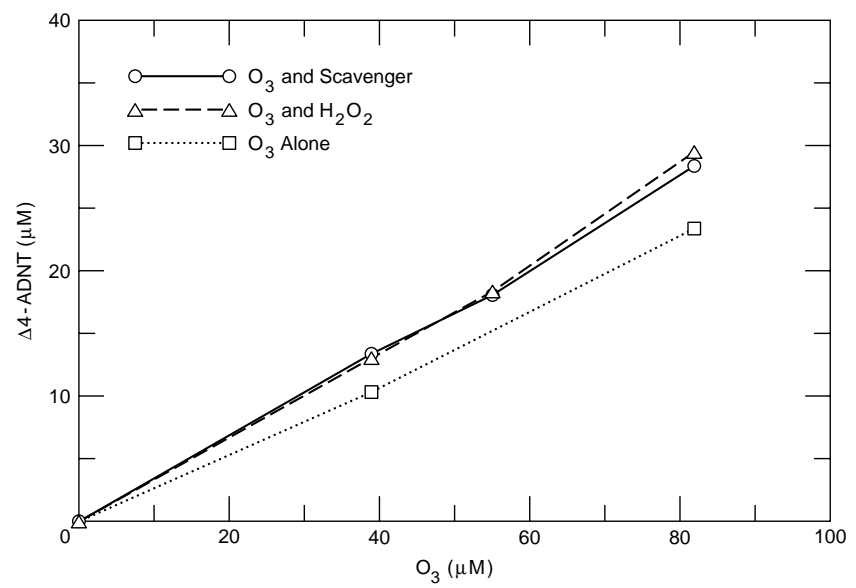

a. 4-ADNT.

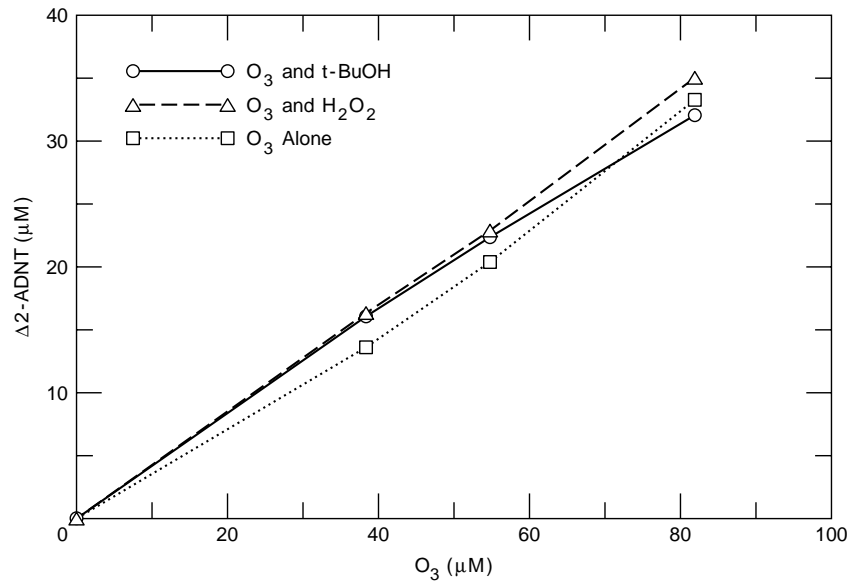

b. 2-ADNT.

Figure 3. Oxidation stoichiometry of 4-ADNT and 2-ADNT in the peroxone, ozone alone, and ozone with scavenger ( $\mathrm{t}-$ butyl alcohol) systems. 


\section{Transformation products}

The identification of transformation products involved those that had UV spectral and chromatographic properties identical to authentic standards. Aldehydes and ketonic intermediates were identified as their 2,4-dinitrophenylhydrazones by high-performance liquid chromatography and diode array UV spectral data. Products resulting from 2-ADNT include glyoxylic acid, pyruvic acid, glyoxal, and pyruvic aldehyde. The structures of these components are shown below.

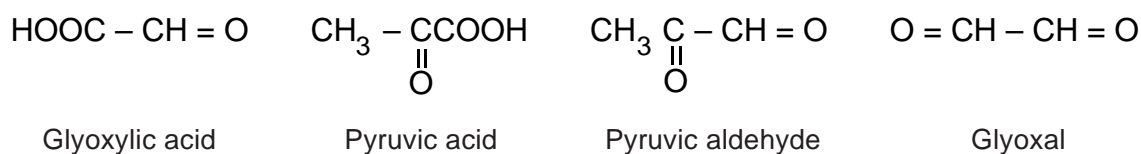

The chromatographic profile for 2-ADNT of the 2,4-dinitrophenylhydrazones appears in Figure 4. There are still numerous products that have not been identified based on the lack of available reference standards.

The 4-ADNT showed a similar set of carbonyl-containing products, but glyoxal was not observed (Fig. 5). In place of glyoxal was another derivative that is believed to contain multiple carbonyl-containing groups based on its chromatography and UV spectral properties (Fig. 6). It appears that these products, although small in concentration, possess multifunctional carbonyl moieties in their structures.

The formation (and decline) of the major known components for 2-ADNT and 4-ADNT are shown in Figure 7 as a function of exposure time to ozone. The aldehyde and ketonic intermediates account for approximately $30 \%$ of the carbon material balance.

Carboxylic acids, chromatographed on the Supelcogel $610 \mathrm{H}$ column and detected at $210 \mathrm{~nm}$,

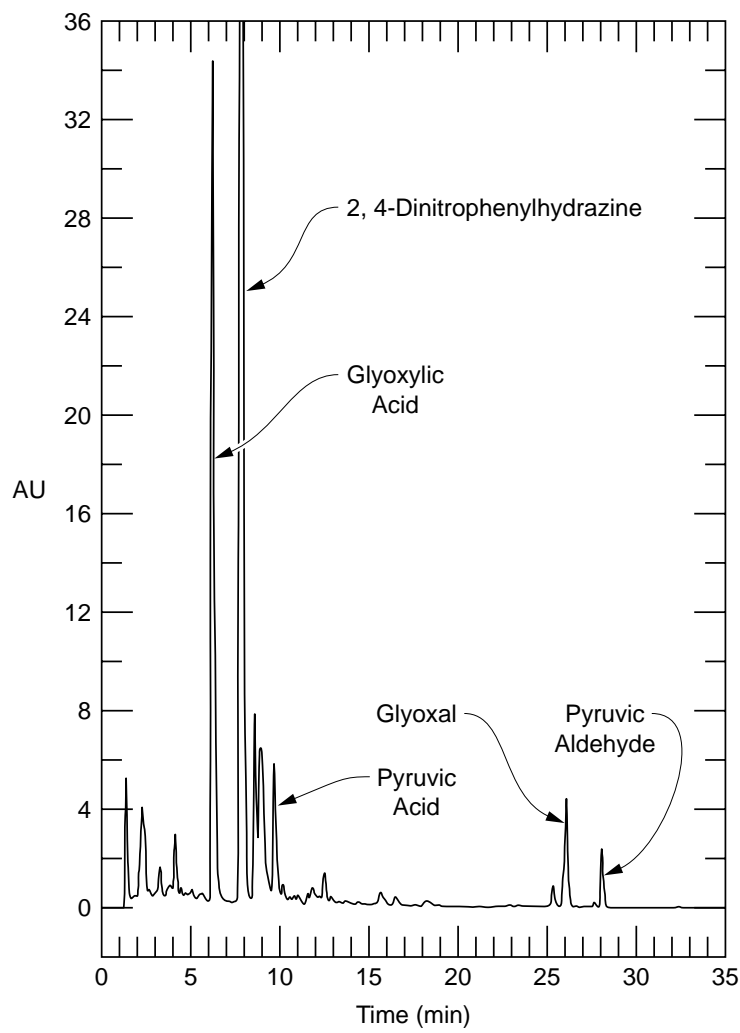

Figure 4. HPLC profile of carbonyl-containing products from the ozonation of 2-ADNT.

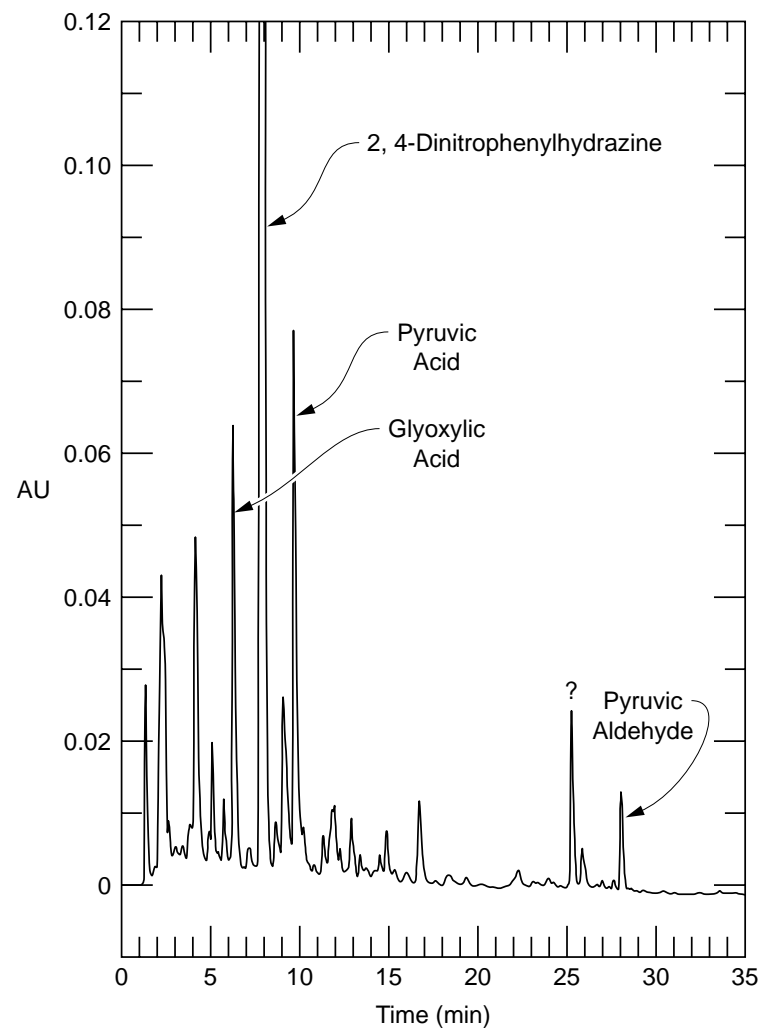

Figure 5. HPLC profile of carbonyl-containing products from the ozonation of 4-ADNT. 


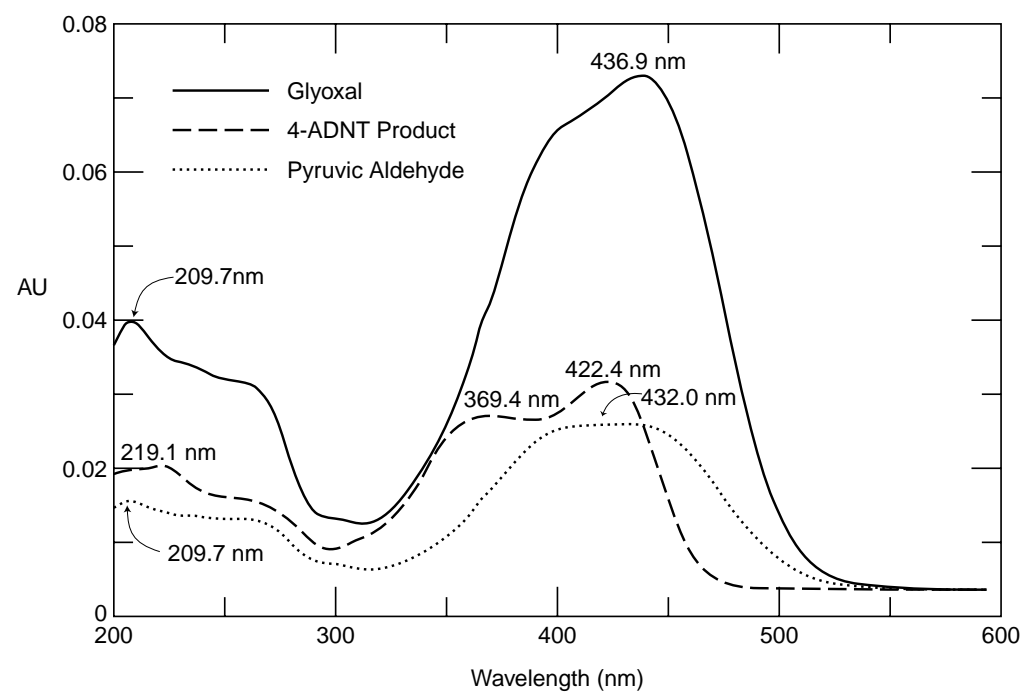

Figure 6. UV spectral data for 4-ADNT product compared to glyoxal and pyruvic aldehyde.

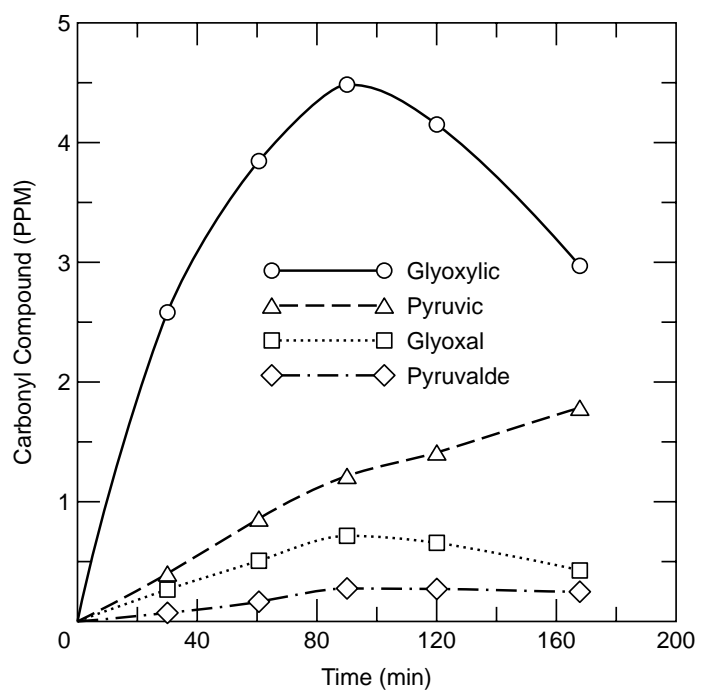

a. 2-ADNT.

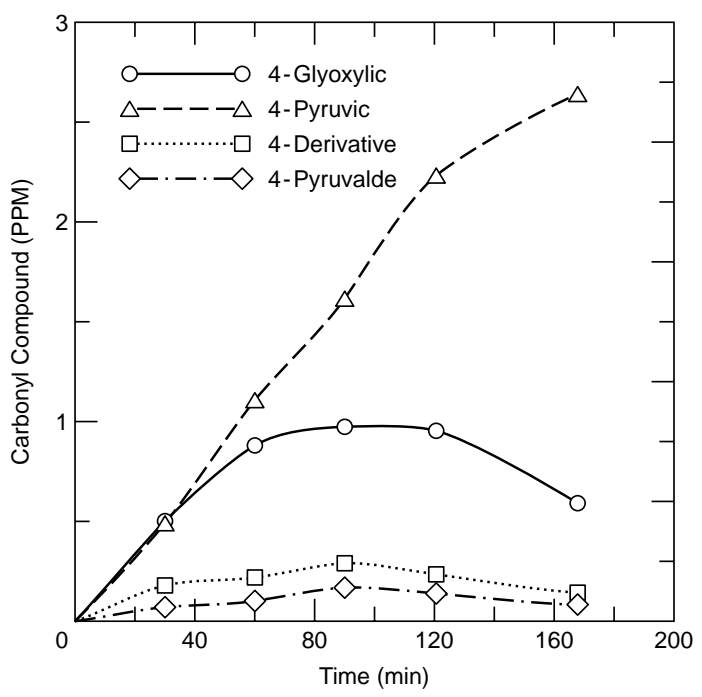

b. 4-ADNT.

Figure 7. Quantitative determination of 2,4-dinitrophenylhydrazone derivatives of products from 2-ADNT and 4-ADNT.

confirmed the generation of pyruvic acid as a stable end-product. Based on chromatographic retention times, glycolic acid $\left(\mathrm{HOCH}_{2} \mathrm{COOH}\right)$ and acetic acid were also identified. Other acids appeared in the profile, but their retention times could not be matched with authentic standards. Oxalic acid eluted near the dead volume and was masked by the large amounts of nitrate ion generated during ozonation. A comparison of acids generated from 2-ADNT and 4-ADNT is shown in Figure 8 and indicates the direct difference in product compositions for identical ozonation times.

Using anion exchange with conductivity detection, nitrate ion could be resolved from oxalic acid and other carboxylic acids. Formic, malonic, oxalic, and acetic acids were observed. The tentative identifications of acids observed by this technique are shown in Figure 9 for 2-ADNT and 4ADNT. The product profile was found not to agree with that observed on the Supelcogel column (with UV detection), especially with respect to formic and pyruvic acids. These results indicate that other methods of confirmatory analysis need to be addressed for the carboxylic acid fraction. 


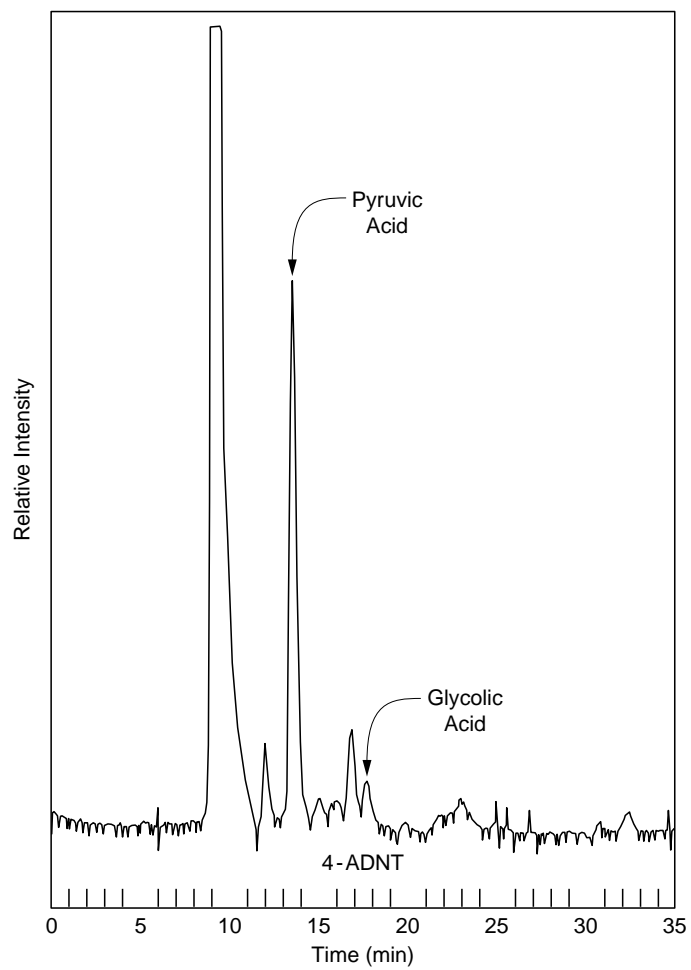

a. 4-ADNT.

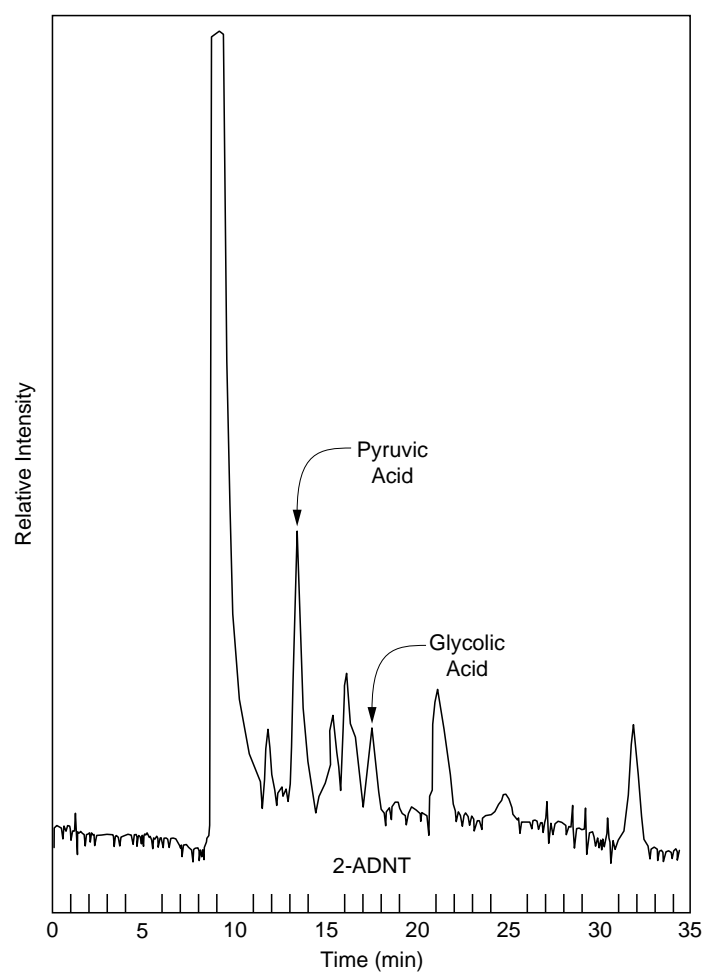

b. 2-ADNT.

Figure 8. HPLC profile of carboxylic acids formed from the ozonation of 4-ADNT and 2-ADNT using UV detection at $210 \mathrm{~nm}$.

\section{Material balance}

A material balance of carbon and nitrogen was estimated based on analytical results of samples subjected to ozonation. Total organic carbon analyses of samples before and after ozonation showed a $120 \%$ recovery of available carbon, suggesting that little mineralization of carbon (i.e., production of $\mathrm{CO}_{2}$ ) occurs during ozonation. A combined product quantitation and graph for 2-ADNT and 4-ADNT appear in Figures 10 and 11. The data indicate that $35 \%$ of the available carbon can be accounted for by identified products.

For nitrogen, $85 \%$ of the available nitrogen was accounted for by nitrite and nitrate. Other nitrogen-containing species such as $\mathrm{NO}$ and $\mathrm{NO}_{2}$ gases were not detected. Plots of nitrite and nitrate formation as a function of ADNT con-

Figure 9. HPLC profile of carboxylic acids generated from the ozonation of 2-ADNT (top) and 4-ADNT (bottom) using conductivity detection.
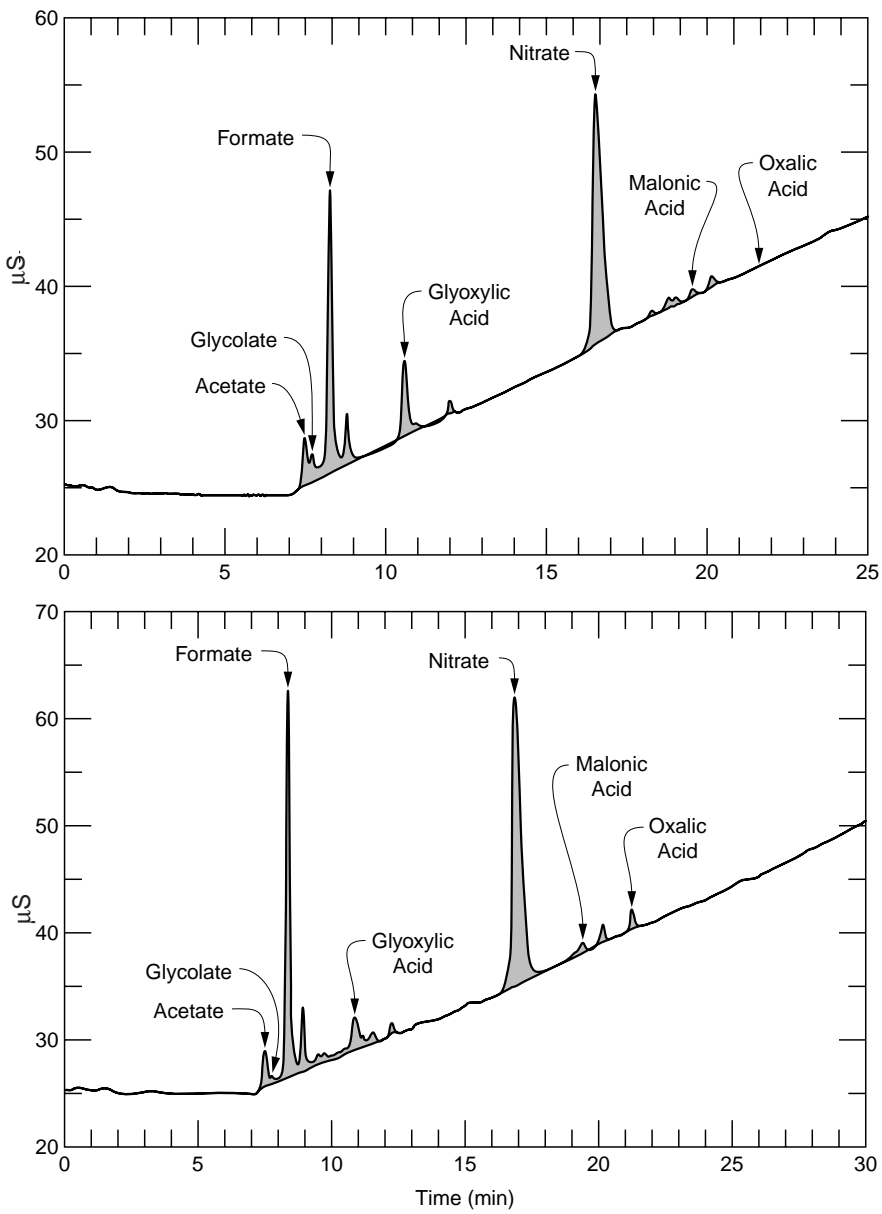


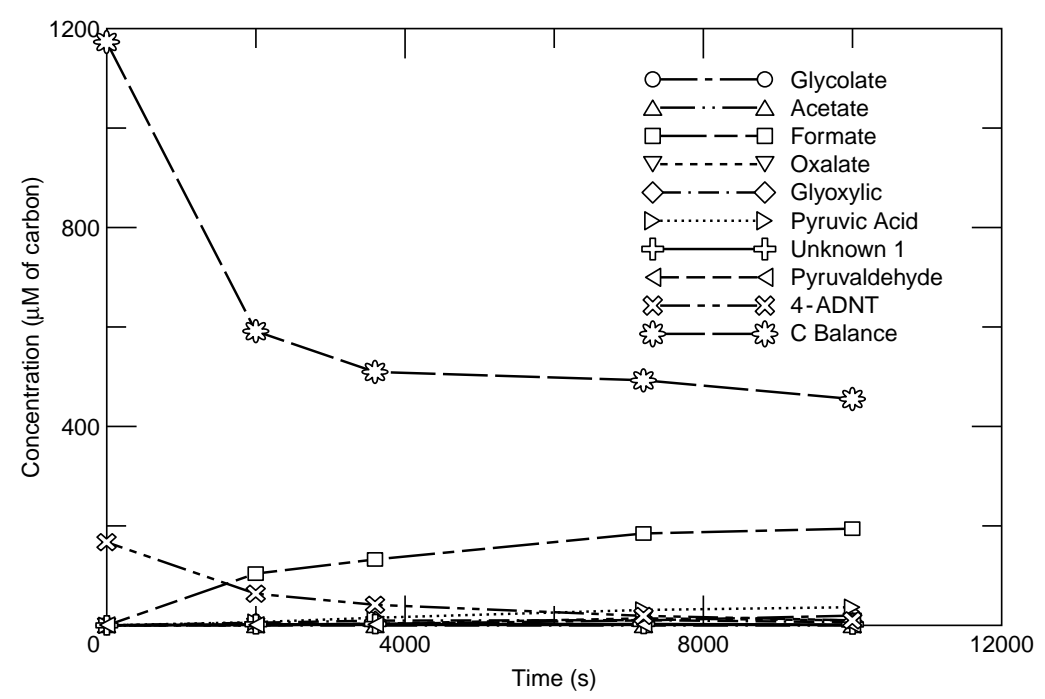

Figure 10. Carbon balance and product distribution from the ozonation of 2-ADNT.

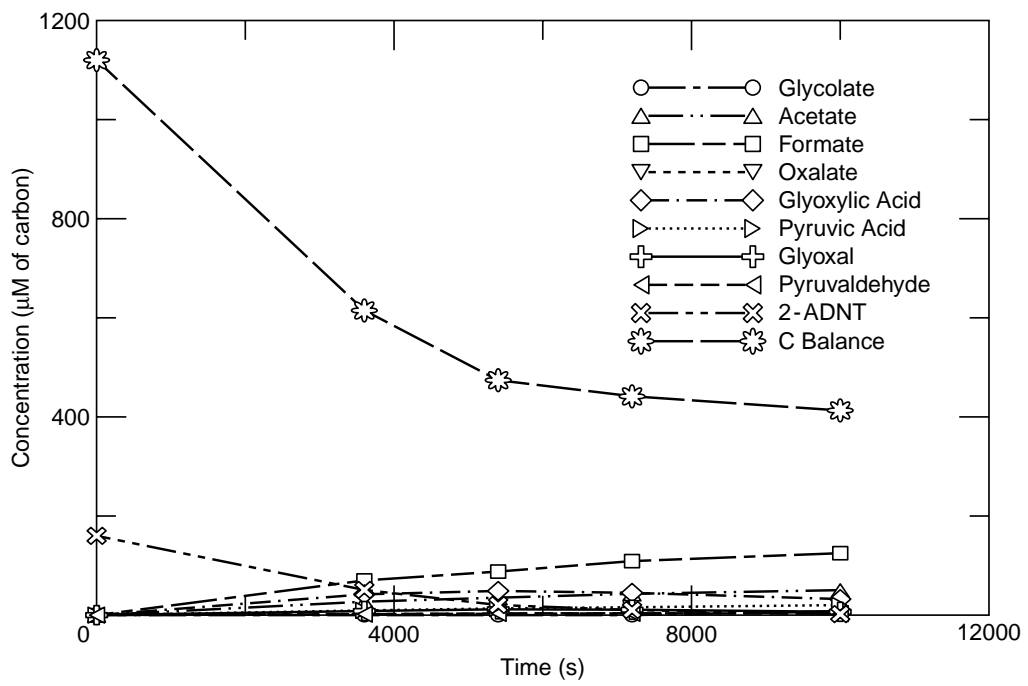

Figure 11. Carbon balance and product distribution from the ozonation of 4-ADNT.

sumed appear in Figure 12. Initially, nitrite concentrations are higher than nitrate; however, nitrite will compete with the ADNT for ozone, resulting in its conversion to nitrate. A typical chromatogram for nitrite and nitrate appears in Figure 13.

\section{DISCUSSION}

ADNTs react rapidly with ozone and hydroxyl radical oxidants in aqueous systems. The peroxone treatment of ADNTs will be controlled by ozone oxidation based on the measured rate constants and relative oxidant concentrations in peroxone systems. Because of the magnitude of the rate constants $\left(10^{5} \mathrm{M}^{-1} \mathrm{~s}^{-1}\right.$ for ozone and $10^{9} \mathrm{M}^{-1} \mathrm{~s}^{-1}$ for hydroxyl radical), competitive oxidation kinetics offers a convenient method to study the reaction kinetics.

The rate constants for the oxidation of 2-ADNT and 4-ADNT by ozone were calculated to be 5.3 $\times 10^{5} \mathrm{M}^{-1} \mathrm{~s}^{-1}$ and $1.9 \times 10^{5} \mathrm{M}^{-1} \mathrm{~s}^{-1}$, respectively, when nitrite was used as a reference chemical. The rate constants for the oxidation of 2-ADNT and 4-ADNT by hydroxyl radical were calculated to be 


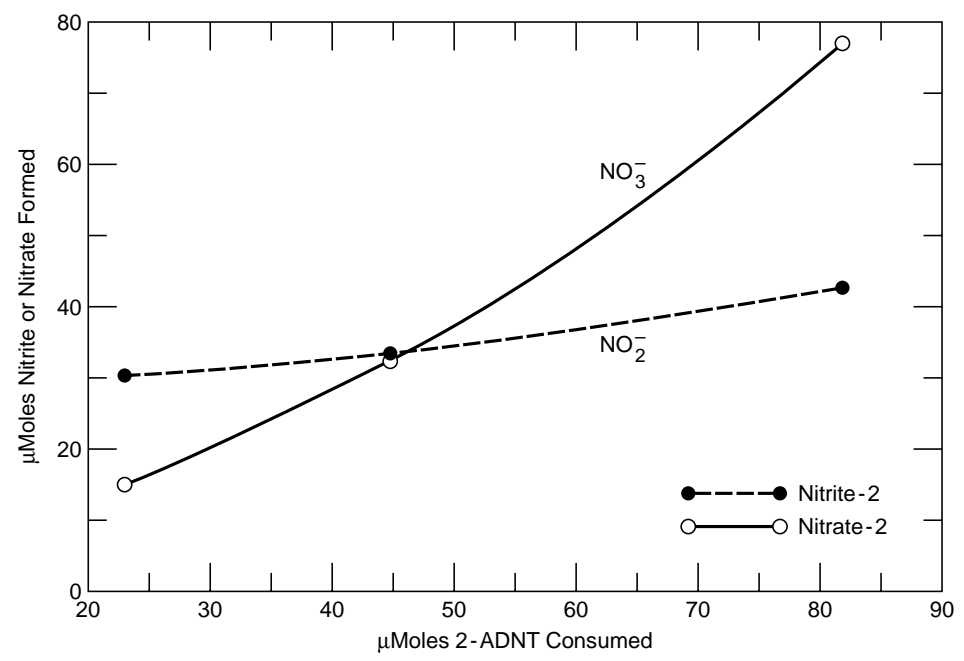

a. 2-ADNT.

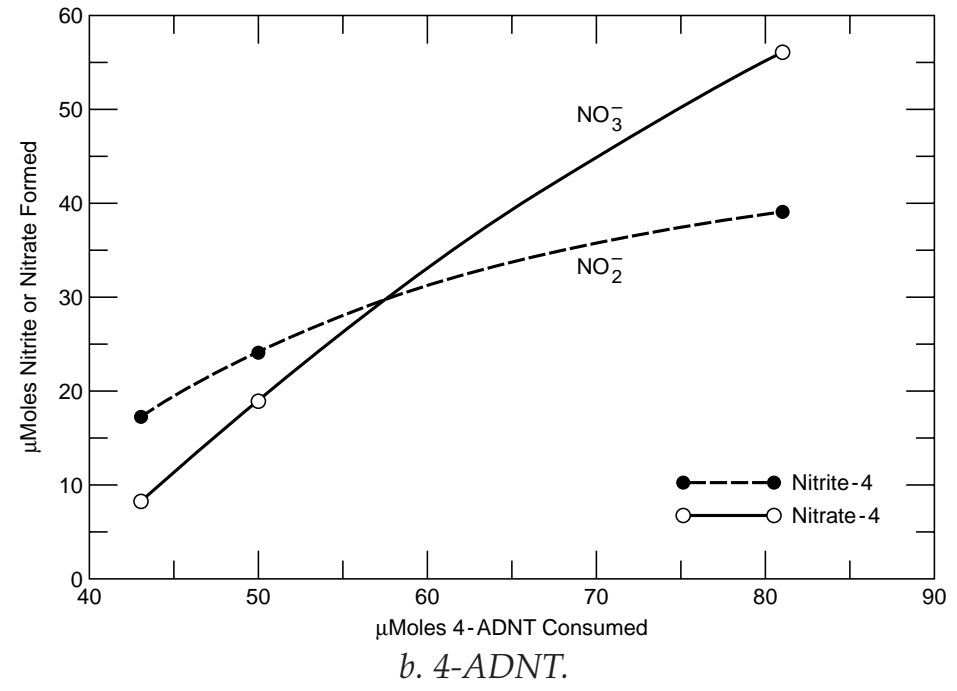

Figure 12. Plots of nitrite and nitrate formation as a function of 2-ADNT and 4-ADNT loss.

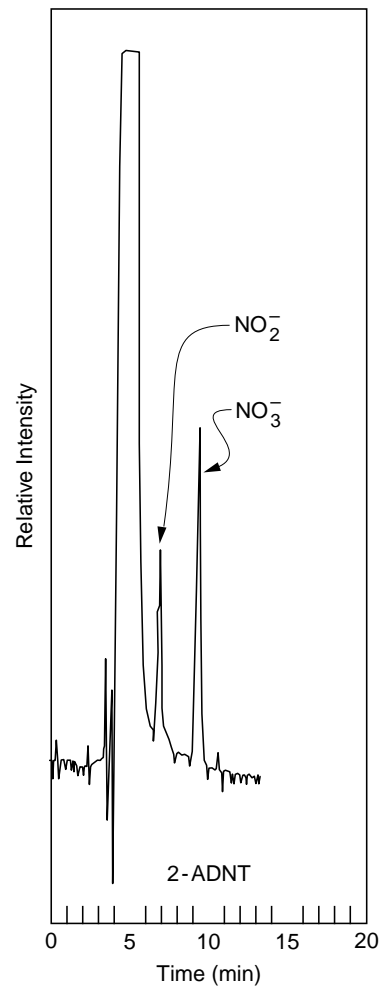

Figure 13. HPLC profile of nitrite and nitrate formation in 2-ADNT oxidation by ozone.

$1.6 \times 10^{9} \mathrm{M}^{-1} \mathrm{~s}^{-1}$ and $1.9 \times 10^{9} \mathrm{M}^{-1} \mathrm{~s}^{-1}$, respectively, when p-nitroacetophenone was used as a reference chemical. If we assume an ozone concentration of $1 \times 10^{-4} \mathrm{M}(4.8 \mathrm{mg} / \mathrm{L})$, we can estimate the hydroxyl radical concentration necessary to make the hydroxyl radical rate $\left(\mathrm{R}_{\mathrm{HO}} \bullet\right)$ competitive with ozone $\left(\mathrm{R}_{\mathrm{O}_{3}}\right)$ by using eq 5 and 2-ADNT as an example:

$$
\begin{aligned}
\mathrm{R}_{\mathrm{O}_{3}} / \mathrm{R}_{\mathrm{HO}} & =\mathrm{k}_{\mathrm{O}_{3}}\left(\mathrm{O}_{3}\right) / \mathrm{k}_{\mathrm{HO}} \cdot[\mathrm{OH} \bullet] \\
& =5.3 \times 10^{5} \mathrm{M}^{-1} \mathrm{~s}^{-1}\left(1 \times 10^{-4} \mathrm{M}\right) / 1.6 \times 10^{9} \mathrm{M}^{-1} \mathrm{~s}^{-1}[\mathrm{HO} \bullet] \\
& =3.3 \times 10^{-8} \mathrm{M} /[\mathrm{HO} \bullet] \\
\text { If } \mathrm{R}_{\mathrm{O}_{3}} / \mathrm{R}_{\mathrm{HO}} \bullet & =1, \text { then }[\mathrm{HO} \bullet]=3.3 \times 10^{-8} \mathrm{M} .
\end{aligned}
$$

Because hydroxyl radical concentration is usually in the $10^{-11}$ to $10^{-14} \mathrm{M}$ range, this oxidative pathway cannot compete with ozone for ADNTs in pure water systems. However, when ADNT concentrations become extremely low (ppb range), the reaction of ozone with hydrogen peroxide will dominate the loss of ozone (compared to the reaction with ADNT) and lead to an increase in the loss of ADNT by the hydroxyl radical pathway. 
The speed of the reaction of ADNTs with ozone and the accompanying reactivity of suspected intermediate products make the study of the mechanistic degradation pathway a challenging endeavor. With the information gained in this study and the current understanding of the chemistry of ozone in aqueous solution, one approach to evaluate pathways is to examine stable end-products and assess how these products may arise.

Pyruvic acid is generated as a major stable end-product from both 2-ADNT and 4-ADNT. The most direct route of formation involves cleavage around the aromatic methyl group as shown below. We propose an ozone-amine adduct as an initial binding step, which ruptures the ring at the 2-3 carbon bond. In a series of steps, nitrite is produced, which is observed early in the oxidations. This pathway would generate pyruvic aldehyde (a found intermediate), which undergoes further oxidation with ozone to produce pyruvic acid.

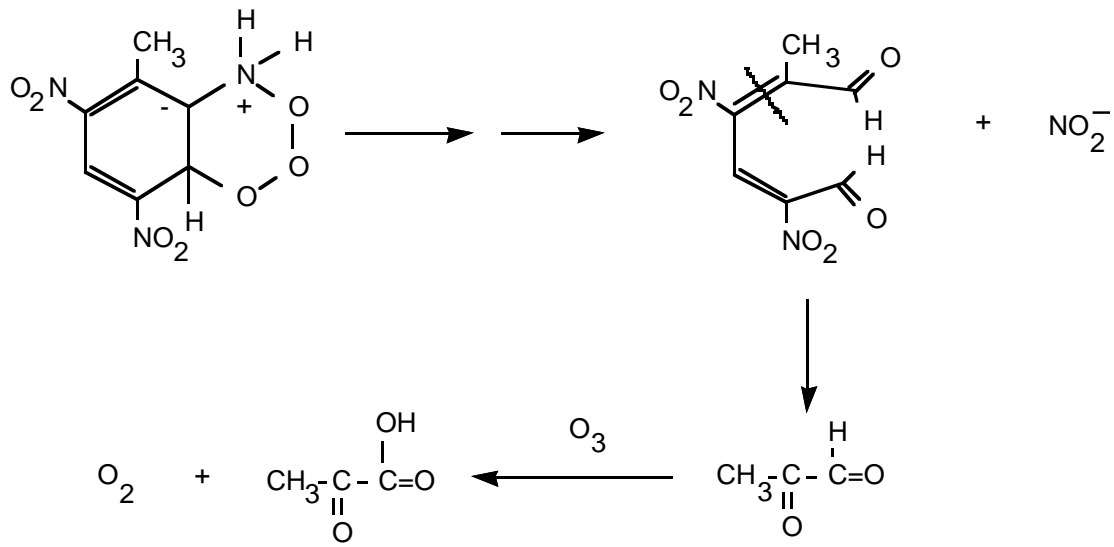

Cleavage on the right side of the carbon atom bearing the methyl group could also lead to pyruvic acid.

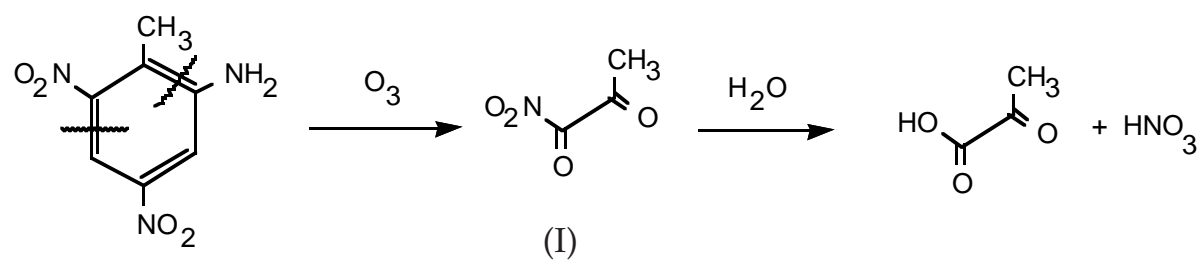

At this time, the behavior of the nitro intermediate (I) is not clear. While hydrolysis is expected, reduction, leading to pyruvic aldehyde and nitrate, cannot be ignored as an alternate route of transformation.

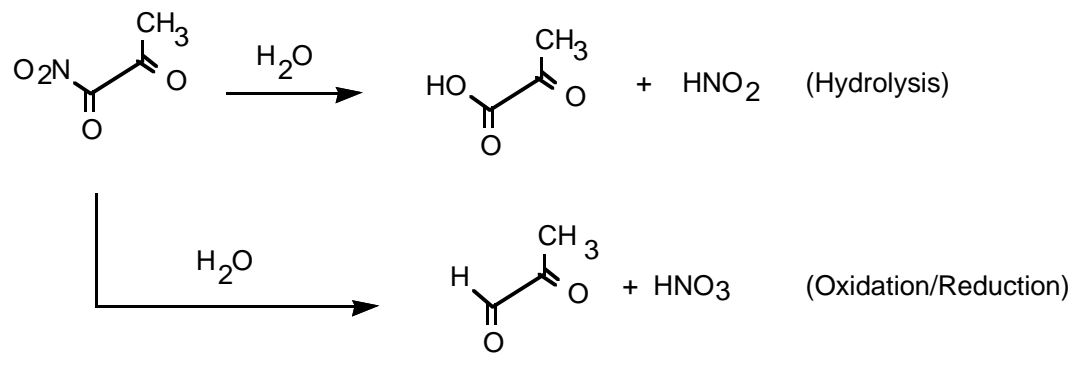

In the current investigation, a potential transformation product studied was oxalacetic acid. This acid formed a 2,4-dinitrophenylhydrazone derivative that could not be found in ozonized solutions. However, on standing, this derivative was converted to pyruvic acid. Therefore, it cannot be ruled out that oxalacetic acid is a precursor to pyruvic acid. 


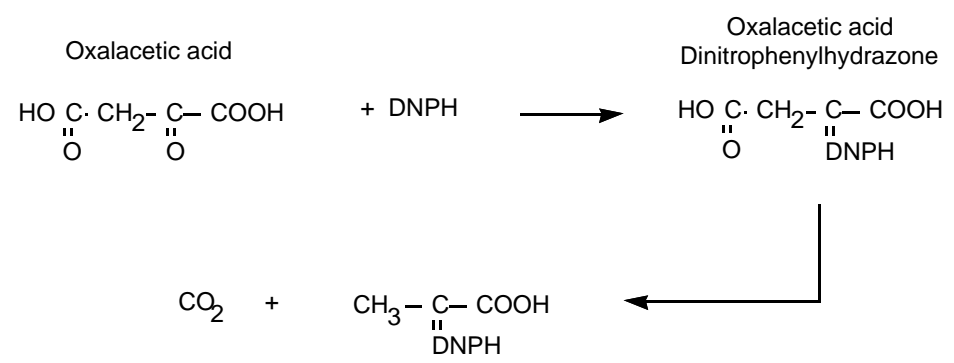

The presence of oxalacetic acid may be derived from the reaction of an isomeric form of the ADNTs.

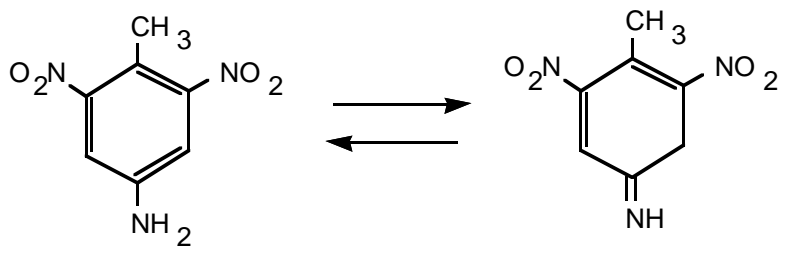

Oxidation at the three double bonds of the isomeric form of 4-ADNT could lead to oxalacetic acid.

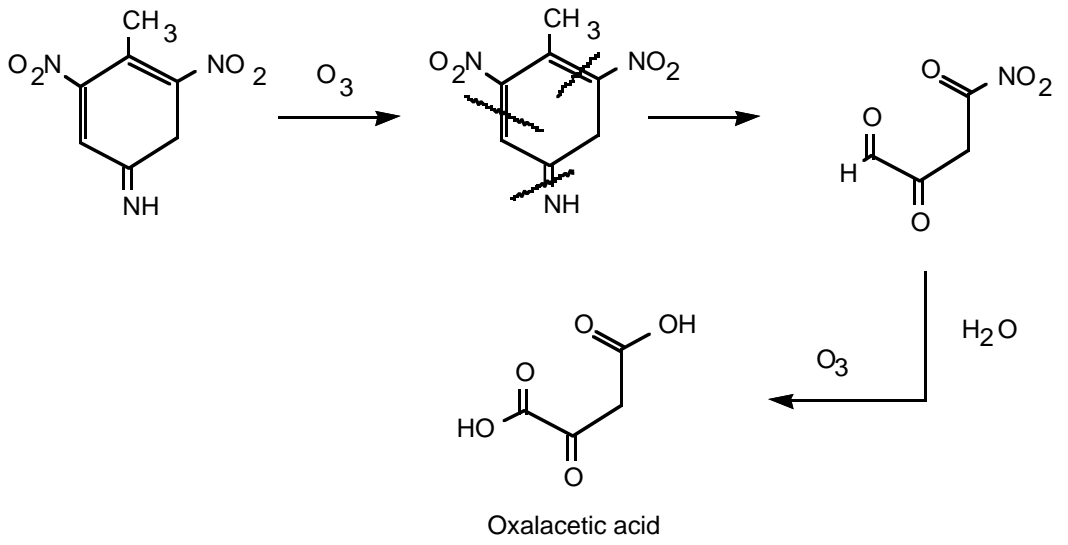

Intermediate aldehydes are possible that also undergo oxidation to the acids with ozone. Thus, it appears that multiple sources of pyruvic acid are possible in the oxidation of ADNTs by ozone.

Glyoxylic acid was observed and confirmed (HPLC retention time and UV spectrum) by the DNPH assay technique as a major transformation product; however, it was not observed in the carboxylic acid profile (UV method), although the reference chemical possesses good chromatographic properties. This suggests that the derivatization conditions, although mild (low $\mathrm{pH}$, room temperature), convert a precursor product to glyoxylic acid. Glyoxylic acid was observed by the conductivity method and its formation could result as shown below.

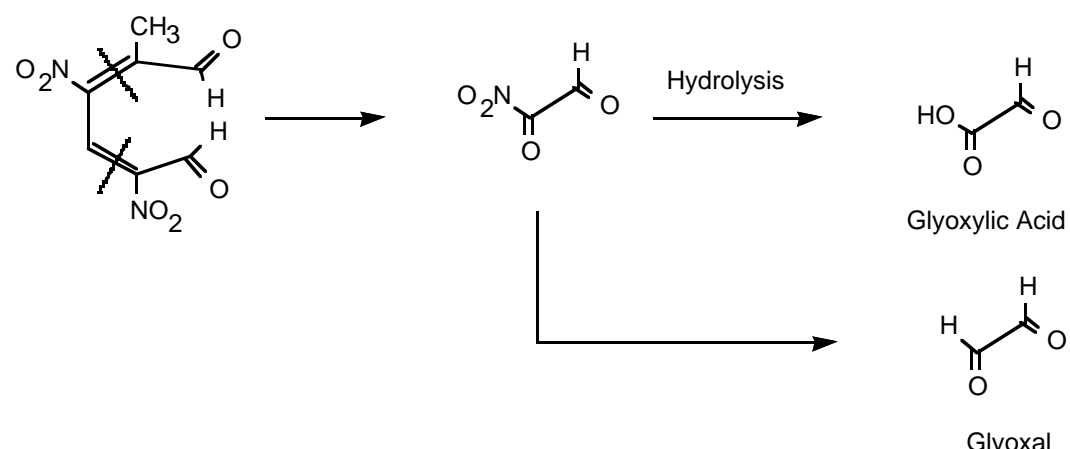


Glyoxal could also be derived by this pathway by an oxidation/reduction process. Both of these compounds would be precursors to oxalic and formic acids.

Differences in carboxylic acid content observed by the UV method and the conductivity method (for example, formic acid and glyoxylic acid) suggest that positive identifications must be addressed by additional techniques.

\section{CONCLUSIONS}

In conclusion, the laboratory oxidation of ADNTs by peroxone AOT proceeds rapidly to primarily innocuous products. Ozone in the peroxone system appears to dominate the ADNT loss process. Product studies indicate that the ring is ruptured readily with the release of nitrite and nitrate ions.

\section{LITERATURE CITED}

Bader, H., and J. Hoigne (1981) Determination of ozone in water by the indigo method. Water Research, 15: 448-456.

Buxton, G.V., and C.L. Greenstoch (1988) Critical reviews of rate constants for reactions of hydrated electrons, hydrogen atoms and hydroxyl radicals $\left(\cdot \mathrm{OH} / \mathrm{O}^{-}\right)$in aqueous solution. Journal of Physical and Chemical Reference Data, 17: 513-886.

Glover, D.J., J.C. Hoffsommer, and D.A. Kubose (1977) Analysis of mixtures of 2-Amino-4,6dinitrotoluene and 4-Amino-2,6-dinitrotoluene, 2,4-Diamino-6-nitrotoluene, and 2,6-Diamino-4nitrotoluene. Analytica Chemica Acta, 88: 381-384.

Hoigne, J., and H. Bader (1983) Rate constants of reactions of ozone with organic and inorganic compounds in water. Water Research, 17: 173-183.

Kieber, R.J., and K. Mopper (1990) Determination of picomolar concentrations of carbonyl compounds in natural waters, including seawater, by liquid chromatography. Environmental Science and Technology, 24(10): 1477-1481.

Setterfield, C.N., and A.H. Bonnel (1955) Interferences in the titanium sulfate method for hydrogen peroxide. Analytical Chemistry, 27: 1174.

Thayer, J.R., and R.C. Huffaker (1980) Determination of nitrate and nitrite by high-performance liquid chromatography: Comparison to other methods for nitrate determination. Analytical Biochemistry, 102(1): 110-119. 
Public reporting burden for this collection of information is estimated to average 1 hour per response, including the time for reviewing instructions, searching existing data sources, gathering and maintaining the data needed, and completing and reviewing the collection of information. Send comments regarding this burden estimate or any other aspect of this collection of information, including suggestion for reducing this burden, to Washington Headquarters Services, Directorate for Information Operations and Reports, 1215 Jefferson Davis Highway, Suite 1204, Arlington, VA 22202-4302, and to the Office of Management and Budget, Paperwork Reduction Project (0704-0188), Washington, DC 20503.

\begin{tabular}{|l|l|l}
\hline 1. AGENCY USE ONLY (Leave blank) & $\begin{array}{l}\text { 2. REPORT DATE } \\
\text { February 1997 }\end{array}$ & 3. REPORT TYPE AND DATES COVERED \\
\hline
\end{tabular}

\begin{tabular}{|l|l|l}
\hline 4. TITLE AND SUBTITLE & 5. FUNDING NUMBERS
\end{tabular}

Investigation of the Kinetics and Products Resulting from the

Reaction of Peroxone with Aminodinitrotoluenes

6. AUTHORS

Ronald J. Spanggord, David Yao, and Theodore Mill

7. PERFORMING ORGANIZATION NAME(S) AND ADDRESS(ES)

8. PERFORMING ORGANIZATION REPORT NUMBER

U.S. Army Cold Regions Research and Engineering Laboratory

Hanover, New Hampshire 03755-1290

Special Report 97-5

9. SPONSORING/MONITORING AGENCY NAME(S) AND ADDRESS(ES)

10. SPONSORING/MONITORING AGENCY REPORT NUMBER

U.S. Army Cold Regions Research and Engineering Laboratory

Hanover, New Hampshire
U.S. Army Engineer Waterways

Experiment Station

Vicksburg, Mississippi

11. SUPPLEMENTARY NOTES

12a. DISTRIBUTION/AVAILABILITY STATEMENT

12b. DISTRIBUTION CODE

Approved for public release; distribution is unlimited.

Available from NTIS, Springfield, Virginia 22161.

13. ABSTRACT (Maximum 200 words)

The reaction between peroxone and two isomers of aminodinitrotoluene (ADNT) was studied with respect to kinetics of reaction and the products formed. The ADNTs react rapidly with ozone and hydroxyl radical, the principal components of peroxone. At fairly high ADNT concentrations (ppm), the reaction of ADNT is primarily with ozone. At lower ADNT concentrations ( $\mathrm{ppb}$ ), hydroxyl radical competes with ozone in pure water systems. Reactions of both the 2- and 4-ADNT isomers result in the formation of pyruvic acid, nitrate ion, and nitrite ion. A reaction mechanism consistent with these products is proposed.

\begin{tabular}{|c|c|c|c|}
\hline \multirow{2}{*}{$\begin{array}{l}\text { 14. SUBJECT TERMS } \\
\text { advanced oxidation } \\
\text { aminodinitrotoluene } \\
\text { hydrogen peroxide }\end{array}$} & \multirow{2}{*}{\multicolumn{2}{|c|}{$\begin{array}{l}\text { hydroxyl radical } \\
\text { ozone } \\
\text { peroxone }\end{array}$}} & $\begin{array}{l}\text { 15. NUMBER OF PAGES } \\
19\end{array}$ \\
\hline & & & 16. PRICE CODE \\
\hline $\begin{array}{l}\text { 17. SECURITY CLASSIFICATION } \\
\text { OF REPORT }\end{array}$ & $\begin{array}{l}\text { 18. SECURITY CLASSIFICATION } \\
\text { OF THIS PAGE }\end{array}$ & $\begin{array}{l}\text { 19. SECURITY CLASSIFICATION } \\
\text { OF ABSTRACT }\end{array}$ & 20. LIMITATION OF ABSTRACT \\
\hline UNCLASSIFIED & UNCLASSIFIED & UNCLASSIFIED & UL \\
\hline
\end{tabular}

